\title{
Desain Sepatu Berpiezoelektrik Sebagai Sistem Pemanen Energi dari Aktivitas Berjalan Manusia
}

\author{
1,2Reza Raditya Pratama, 1,2Muhammad Faizal Sofyan \& ${ }^{1,2}$ Estiyanti Ekawati \\ 1Program Studi S1 Teknik Fisika, Fakultas Teknologi Industri, \\ Institut Teknologi Bandung (ITB), Bandung, Indonesia \\ 2Pusat Teknologi Instrumentasi dan Otomasi, Institut Teknologi Bandung (ITB), Bandung, Indonesia \\ rezaraditya39@gmail.com, m.faizalsofyan@gmail.com, esti@instrument.itb.ac.id
}

\begin{abstract}
Abstrak
Sepatu berpiezoelektrik merupakan salah satu teknologi yang dikembangkan untuk memanfaatkan potensi aktivitas berjalan manusia sebagai sumber energi terbarukan. Sistem sepatu berpiezoelektrik pada studi ini terdiri dari integrasi antara konfigurasi piezoelektrik dengan konverter yang diletakan di dalam sol sepatu. Studi ini telah melalui beberapa tahap desain dan tahap uji untuk memeroleh sistem yang tepat untuk memanen energi dari aktivitas berjalan manusia. Pada penelitian ini, diseleksi delapan desain konfigurasi piezoelektrik, dengan variasi tipe piezoelektrik, jenis dan ketebalan material insole, jenis konverter dan jenis kapasitor penyimpan muatan listrik. Pemilihan desain dilaksanakan melalui beberapa tahap uji. Tahap uji tersebut meliputi uji langkah kaki, uji menggunakan impact hammer, dan uji konverter. Sistem terpilih berdasarkan tiga tahap uji tersebut terdiri dari konfigurasi piezoelektrik K7520BP2 dengan 3mm Evafoam Angin sebagai insole, dan konverter MB39C811. Tegangan terukur pada kapasitor $10 \mathrm{mF}$ yaitu $1,65 \mathrm{Volt}$ ketika diberi masukan berfrekuensi $2 \mathrm{~Hz}$ selama 20 menit sehingga total muatan listrik tersimpan yaitu $16,5 \mathrm{mC}$.

Kata Kunci: sepatu berpiezoelektrik; sumber energi terbarukan; aktivitas berjalan manusia.
\end{abstract}

\section{Pendahuluan}

Dewasa ini, energi listrik merupakan kebutuhan pokok manusia untuk dapat melaksanakan aktivitas sehari-hari. Hal tersebut menyebabkan peningkatan konsumsi listrik setiap tahun. Di Indonesia, konsumsi listrik per kapita pada tahun 2011 mencapai 679,70kWh. Konsumsi listrik yang terus meningkat ini harus diimbangi dengan ketersediaan sumber energi listrik baru dan terbarukan.

Aktivitas manusia sehari-hari berpotensi menghasilkan daya yang dapat digunakan sebagai sumber energi. Contohnya adalah aktivitas berjalan [1]. Fakta itu memicu penelitian mengenai bahan piezoelektrik sebagai modul pemanen energi yang memanfaatkan aktivitas manusia. Salah satunya adalah Zhao dan You [2], yang mengembangkan sepatu berpiezoelektrik untuk menghasilkan energi listrik dari aktivitas berjalan manusia. Studi tersebut mengembangkan dua purwarupa sol sepatu berpiezoelektrik. Purwarupa pertama terbuat dari multilayer PVDF film dan sturuktur plastik yang dirancang untuk diletakkan di bawah tumit, sedangkan purwarupa kedua dirancang sebagai insole yang terbuat dari flexible silicone rubber dan dua multilayer PVDF film. Lebih banyak energi listrik yang dapat dihasilkan oleh purwarupa pertama, sedangkan purwarupa kedua lebih nyaman digunakan.

Paper ini melaporkan penelitian yang mengadaptasi pendekatan Zhou dan You [2] pada desain sol sepatu berpiezoelektrik yang terdiri dari konfigurasi piezoelektrik dan konverter yang dirancang untuk diletakkan pada bagian midsole di dalam sol sepatu, sehingga lebih nyaman dikenakan. Penelitian ini juga menggunakan bahan piezoelektrik PZT yang lebih ekonomis dibandingkan dengan PVDF. Namun untuk mengatasi sifat bahan PZT yang lebih rapuh, diperlukan konfigurasi material yang mampu melindungi bahan PZT agar bertahan lama.

Pada penelitian ini, dilakukan seleksi terhadap delapan buah desain sol, dengan pilihan variasi tipe piezoelektrik PZT (K7520BP2 dan audio generik), jenis dan ketebalan material penyusun sol (Eva-foam Angin dan Eva-foam Keras), jenis konverter (MB39C811 dan LTC3588-1), serta jenis kapasitor sebagai media penyimpanan (kapasitansi 0,1mF, 1mF, dan 10mF). Pemilihan desain dilaksanakan melalui beberapa tahap uji. Tahap uji tersebut meliputi uji langkah kaki, uji pukul menggunakan impact hammer, dan uji efisiensi konverter.

\section{Metode Perancangan}

Umumnya, piezoelektrik bermaterial PVDF lebih sering diaplikasikan untuk memanfaatkan potensi aktivitas berjalan manusia pada sepatu berpiezoelektrik karena fleksibilitasnya, tetapi piezoelektrik yang digunakan pada studi ini yaitu piezoelektrik berbahan PZT karena lebih mudah 
didapatkan. Piezoelektrik berbahan PZT lebih kaku dan lebih mudah patah, sehingga diperlukan konfigurasi untuk mengatasi sifat tersebut tetapi tetap mampu memanfaatkan potensi aktivitas berjalan manusia sebagai sumber energi terbarukan.

Konfigurasi yang dirancang pada studi ini, adalah konfigurasi piezoelektrik yang diletakkan pada bagian midsole di dalam sol sepatu. Konfigurasi tersebut dilengkapi dengan push button pada bagian atas piezoelektrik sehingga tekanan ketika pengguna berjalan lebih terpusat pada bagian tengah piezoelektrik. Push button yang digunakan pada konfigurasi piezoelektrik terbuat dari material insole yang merupakan salah satu material penyusun struktur sol sepatu.

Terdapat dua tipe piezoelektrik yang diseleksi untuk digunakan, yaitu piezoelektrik pemanen energi K7520BP2 dan piezoelektrik audio generik. Terdapat pula beberapa jenis material yang diseleksi untuk digunakan sebagai material penyusun struktur sol sepatu, seperti pada Tabel 1. Pengaruh ketebalan material penyusun bagian insole akan diuji untuk menentukan konfigurasi piezoelektrik terbaik dan yang paling tepat untuk memanen energi dari aktivitas berjalan manusia.

Konfigurasi piezoelektrik terbaik ditentukan melalui uji langkah kaki dan uji menggunakan impact hammer. Setelah konfigurasi piezoelektrik telah ditentukan, sistem sepatu berpiezoelektrik yang mengintegrasikan konfigurasi piezoelektrik terbaik dengan konverter diuji performanya melalui uji konverter. Sistem berkinerja terbaik dipilih sebagai sistem yang paling tepat untuk memanfaatkan potensi aktivitas berjalan manusia sebagai sumber energi terbarukan pada penelitian ini.

\subsection{Konfigurasi Piezoelektrik}

Pada studi ini, dua tipe piezoelektrik (K7520BP2 dan audio generik) dan dua jenis material penyusun insole dengan ketebalan yang divariasikan merupakan materi penyusun konfigurasi piezoelektrik di dalam sol sepatu. Desain konfigurasi piezoelektrik dengan dua tipe piezoelektrik yang berbeda disesuaikan dengan tipe piezoelektrik tersebut, sedangkan desain struktur sol ditetapkan berdasarkan struktur sol sepatu konvensional yang terdiri dari tiga lapisan sol sepatu, yaitu insole, midsole, dan outsole.

Konfigurasi piezoelektrik diletakkan pada bagian tumit sepatu berpiezoelektrik untuk memeroleh gaya maksimal dari aktivitas berjalan manusia [3]. Setiap konfigurasi piezoelektrik dilengkapi dengan push button berukuran $1 \mathrm{~mm} \times 1 \mathrm{~mm} \times 3 \mathrm{~mm}$ pada bagian atas piezoelektrik.

Tabel 1 Spesifikasi Struktur Sol Sepatu Berpiezoelektrik

\begin{tabular}{|c|c|c|}
\hline Struktur Sol & Jenis Sol & Ketebalan \\
\hline Insole & $\begin{array}{c}\text { Eva-foam Angin atau } \\
\text { Eva-foam Keras }\end{array}$ & $\begin{array}{c}3 \mathrm{~mm} \text { atau } \\
6 \mathrm{~mm}\end{array}$ \\
\hline Midsole & Eva-foam Keras & $10 \mathrm{~mm}$ \\
\hline Outsole & Sol Karet & $12 \mathrm{~mm}$ \\
\hline
\end{tabular}

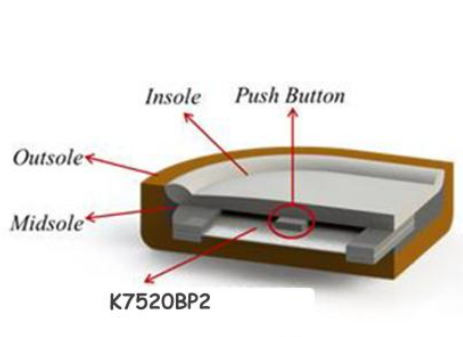

(a)

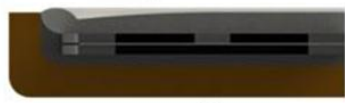

(c)

Gambar 1 (a) Susunan Bahan Konfigurasi K7520BP2 (b) Skema Konfigurasi K7520BP2 (c) Tampak Samping Konfigurasi K7520BP2

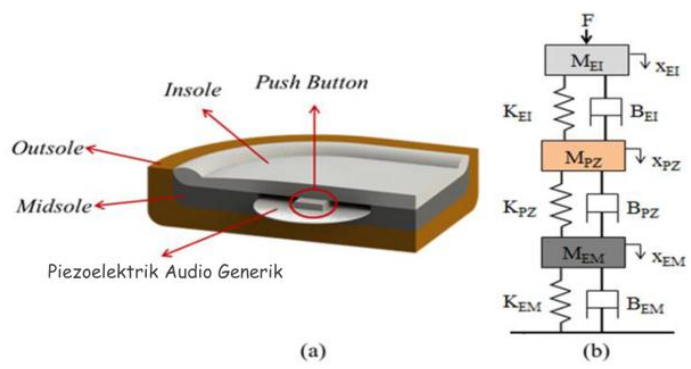

Gambar 2 (a) Konfigurasi Bahan Konfigurasi Piezoelektrik Audio Generik (b) Skema Konfigurasi Piezoelektrik Audio Generik

Masing-masing konfigurasi diilustrasikan oleh Gambar 1 (konfigurasi K7520BP2) dan Gambar 2 (konfigurasi audio generik). Pada konfigurasi K7520BP2, piezoelektrik K7520BP2 dijepit dengan akrilik pada kedua ujungnya serta ditambahkan ruang kosong di bawah piezoelektrik K7520BP2 untuk memaksimalkan defleksi pada piezoelektrik.

Pada konfigurasi piezoelektrik audio generik, tidak terdapat ruang kosong di bawah piezoelektrik karena piezoelektrik tipe ini membutuhkan bantalan untuk membantunya kembali ke posisi semula setelah terdefleksi. 
Skema konfigurasi piezoelektrik pada Gambar 1 (b) dan Gambar 2 (b) menunjukkan penambahan massa insole $\left(\mathrm{M}_{\mathrm{EI}}\right)$ akan mengurangi efek dari gaya yang diberikan manusia ketika berjalan. Elastisitas material insole juga akan memengaruhi defleksi pada piezoelektrik. Defleksi pada piezoelektrik berkurang ketika nilai konstanta pegas material insole $\left(\mathrm{K}_{\mathrm{EI}}\right)$ semakin besar.

Kontribusi parameter-parameter yang terlibat pada proses terdefleksinya piezoelektrik oleh persamaan 1 (konfigurasi K7520BP2) dan persamaan 2 (konfigurasi audio generik) yang didasarkan pada pemodelan piezoelektrik sebagai akselerometer [4]. Arti parameter yang ditampilkan pada persamaan 1 dan persamaan 2 dapat diikuti pada nomenklatur.

$$
\left[\begin{array}{c}
\dot{x}_{E I} \\
\ddot{x}_{E I} \\
\dot{x}_{P Z} \\
\ddot{x}_{P Z}
\end{array}\right]=\left[\begin{array}{cccc}
0 & 1 & 0 & 0 \\
\frac{-K_{E I}}{M_{E I}} & \frac{-B_{E I}}{M_{E I}} & \frac{K_{E I}}{M_{E I}} & \frac{B_{E I}}{M_{E I}} \\
0 & 0 & 0 & 1 \\
\frac{K_{E I}}{M_{P Z}} & \frac{B_{E I}}{M_{P Z}} & \frac{-K_{E I}-K_{P Z}}{M_{P Z}} & \frac{-B_{E I}-B_{P Z}}{M_{P Z}}
\end{array}\right]\left[\begin{array}{c}
\mathrm{x}_{E I} \\
\dot{x}_{E I} \\
\mathrm{x}_{P Z} \\
\dot{x}_{P Z}
\end{array}\right]+\left[\begin{array}{c}
0 \\
\frac{1}{M_{E I}} \\
0 \\
0
\end{array}\right] \mathrm{F}
$$

$$
\left[\begin{array}{l}
\dot{x}_{E I} \\
\dot{x}_{E I} \\
\dot{x}_{P Z} \\
\dot{x}_{P Z} \\
\dot{x}_{E M} \\
\ddot{x}_{E M}
\end{array}\right]\left[\begin{array}{cccccc}
0 & 1 & 0 & 0 & 0 & 0 \\
\frac{-K_{E I}}{M_{E I}} \frac{-B_{E I}}{M_{E I}} & \frac{K_{E I}}{M_{E I}} & \frac{B_{E I}}{M_{E I}} & 0 & 0 \\
0 & 0 & 0 & 1 & 0 & 0 \\
\frac{K_{E I}}{M_{P Z}} & \frac{B_{E I}}{M_{P Z}} & \frac{-K_{E I}-K_{P Z}}{M_{P Z}} \frac{-B_{E I}-B_{P Z}}{M_{P Z}} & \frac{K_{P Z}}{M_{P Z}} & \frac{B_{P Z}}{M_{P Z}} \\
0 & 0 & 0 & 0 & 0 & 1 \\
0 & 0 & \frac{K_{P Z}}{M_{E M}} & \frac{B_{P Z}}{M_{E M}} & \frac{-K_{P Z}-K_{E M}}{M_{E M}} \frac{-B_{P Z}-B_{E M}}{M_{E M}}
\end{array}\right]\left[\begin{array}{c}
x_{E I} \\
\dot{x}_{E I} \\
x_{P Z} \\
\dot{x}_{P Z} \\
x_{E M} \\
\dot{x}_{E M}
\end{array}\right]\left[\begin{array}{c}
0 \\
\frac{1}{M_{E I}} \\
0 \\
0 \\
0 \\
0 \\
0
\end{array}\right] \mathrm{F}
$$

Terdapat delapan buah desain konfigurasi piezoelektrik dengan variasi pada jenis dan ketebalan insole yang ditunjukkan oleh Tabel 2.

\begin{tabular}{|c|c|c|c|}
\hline $\begin{array}{c}\text { Nomor } \\
\text { Konfigurasi }\end{array}$ & $\begin{array}{c}\text { Tipe } \\
\text { Piezoelektrik }\end{array}$ & $\begin{array}{l}\text { Jenis } \\
\text { Insole }\end{array}$ & $\begin{array}{l}\text { Tebal } \\
\text { Insole }\end{array}$ \\
\hline 1 & \multirow{4}{*}{ K7520BP2 } & \multirow{2}{*}{$\begin{array}{l}\text { Eva-foam } \\
\text { Angin }\end{array}$} & $3 \mathrm{~mm}$ \\
\hline 2 & & & $6 \mathrm{~mm}$ \\
\hline 3 & & \multirow{2}{*}{$\begin{array}{c}\text { Eva-foam } \\
\text { Keras }\end{array}$} & $3 \mathrm{~mm}$ \\
\hline 4 & & & $6 \mathrm{~mm}$ \\
\hline 5 & \multirow{4}{*}{$\begin{array}{c}\text { Piezoelektrik } \\
\text { Audio } \\
\text { Generik }\end{array}$} & \multirow{2}{*}{$\begin{array}{l}\text { Eva-foam } \\
\text { Angin }\end{array}$} & $3 \mathrm{~mm}$ \\
\hline 6 & & & $6 \mathrm{~mm}$ \\
\hline 7 & & \multirow{2}{*}{$\begin{array}{l}\text { Eva-foam } \\
\text { Keras }\end{array}$} & $3 \mathrm{~mm}$ \\
\hline 8 & & & $6 \mathrm{~mm}$ \\
\hline
\end{tabular}

Tabel 2 Pilihan Desain Konfigurasi Piezoelektrik

Konfigurasi piezoelektrik tersebut diseleksi melalui dua tahap uji untuk membuktikan hipotesis yang didasarkan pada persamaan 1 dan persamaan 2 .

\subsection{Pengujian}

Pengujian diawali dengan uji langkah kaki yang bertujuan untuk mengetahui tegangan listrik yang dihasilkan oleh konfigurasi uji ketika diberikan gaya berupa pijakan kaki manusia dengan berat 65kg (Gambar 3). Konfigurasi piezoelektrik yang diletakkan pada bagian midsole di dalam sol sepatu dihubungkan pada osiloskop digital sehingga terukur tegangan keluaran konfigurasi piezoelektrik ketika penguji melangkahkan kakinya.

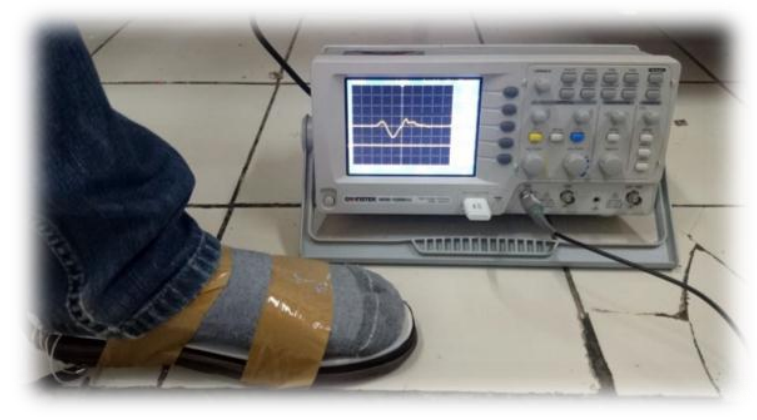

Gambar 3 Pelaksanaan Uji Langkah Kaki

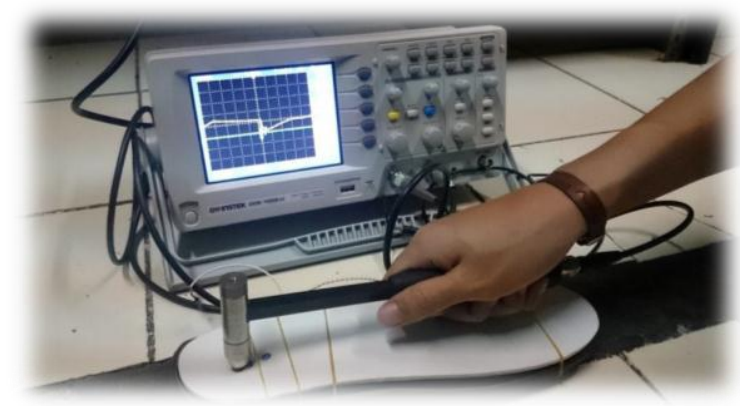

Gambar 4 Pelaksanaan Uji Menggunakan Impact Hammer

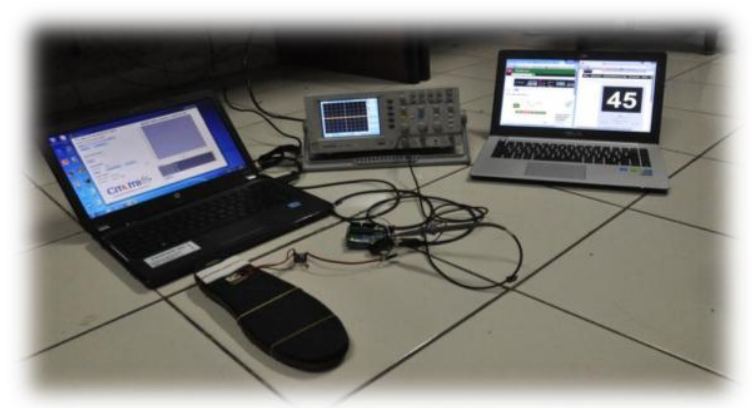

Gambar 5 Pelaksanaan Uji Konverter

Pengujian tahap kedua adalah uji pukul menggunakan impact hammer yang bertujuan untuk mengukur tegangan listrik yang dihasilkan oleh konfigurasi uji ketika diberikan gaya oleh impact hammer (Gambar 4). Pada percobaan tahap kedua, baik konfigurasi uji maupun impact 
hammer terhubung dengan osiloskop digital sehingga baik tegangan keluaran konfigurasi piezoelektrik maupun gaya yang diberikan oleh impact hammer dapat diukur. Gaya impact hammer diukur dengan cara mengalikan tegangan keluaran impact hammer ketika dipukulkan dengan nilai sensitivitas instrumen tersebut.

Pengujian tahap ketiga adalah uji konverter yang bertujuan untuk mengetahui besarnya tegangan listrik yang dihasilkan oleh kapasitor setelah menampung muatan listrik dari sistem sepatu berpiezoelektrik (Gambar 5). Sistem sepatu berpiezoelektrik merupakan integrasi dari konfigurasi piezoelektrik yang memiliki tegangan keluaran terbaik berdasarkan hasil uji menggunakan impact hammer dengan konverter. Pada pengujian ini, sistem sepatu berpiezoelektrik yang terhubung dengan kapasitor dipukul dengan frekuensi yang disesuaikan dengan langkah cepat manusia oleh impact hammer selama periode waktu tertentu. Pada waktu yang sama dengan pemberian gaya impact hammer pada sistem sepatu berpiezoelektrik, tegangan pada kapasitor diukur setiap 10 detik.

\section{Hasil dan Diskusi}

Realisasi masing-masing konfigurasi piezoelektrik ditunjukkan pada Gambar 6 (konfigurasi K7520BP2) dan Gambar 7 (konfigurasi audio generik).

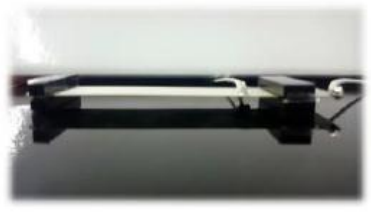

(a)

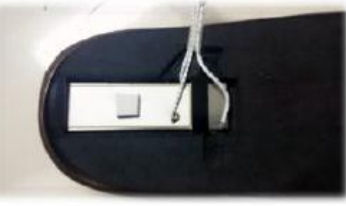

Gambar 6 Realisasi Konfigurasi K7520BP2 (a) Konstruksi K7520BP2 (b) Konfigurasi K7520BP2 di dalam Sol

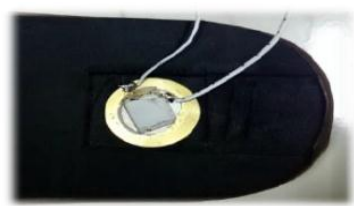

(a)

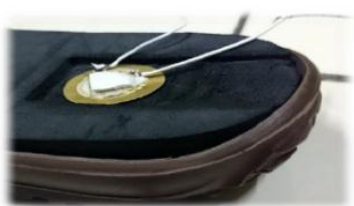

(b)
Gambar 7 Realisasi Konfigurasi Piezoelektrik Audio Generik (a) Tampak Atas (b) Tampak Samping

Berdasarkan data uji langkah kaki pada Tabel 3, penambahan ketebalan insole, yang sebanding dengan penambahan massa insole (MEI), berpengaruh pada tegangan keluaran konfigurasi piezoelektrik. Konfigurasi piezoelektrik nomor 1 sampai 6 menunjukkan penambahan ketebalan material insole mengurangi tegangan keluaran konfigurasi piezoelektrik, dengan perkecualian pada konfigurasi piezoelektrik audio generik dengan insole jenis Eva-foam Keras.

Tabel 3 Data Uji Langkah Kaki

\begin{tabular}{|c|c|c|c|}
\hline \multirow{2}{*}{$\begin{array}{c}\text { Nomor } \\
\text { Konfigurasi }\end{array}$} & \multicolumn{3}{|c|}{ Tegangan Keluaran (Volt) } \\
\cline { 2 - 4 } & Min & Maks & Rata-rata \\
\hline 1 & 15,60 & 35,60 & 26,40 \\
\hline 2 & 10,40 & 20,40 & 16,52 \\
\hline 3 & 14,00 & 19,20 & 16,32 \\
\hline 4 & 8,80 & 18,40 & 12,17 \\
\hline 5 & 6,00 & 30,40 & 15,11 \\
\hline 6 & 8,00 & 18,00 & 12,05 \\
\hline 7 & 10,40 & 24,00 & 16,21 \\
\hline 8 & 14,40 & 32,00 & 23,53 \\
\hline
\end{tabular}

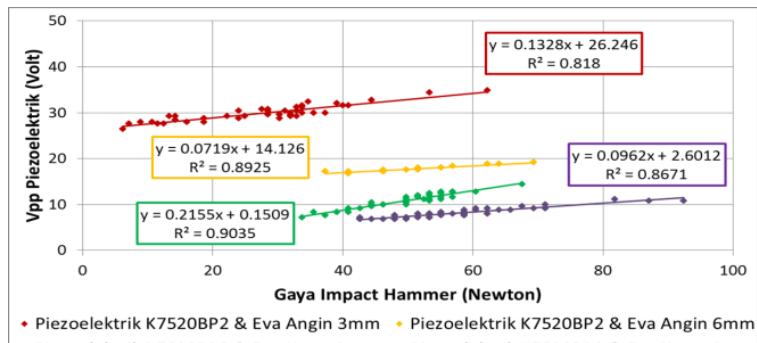

- Piezoelektrik K7520BP2 \& Eva Keras 3mm • Piezoelektrik K7520BP2 \& Eva Keras $6 \mathrm{~mm}$

(a)

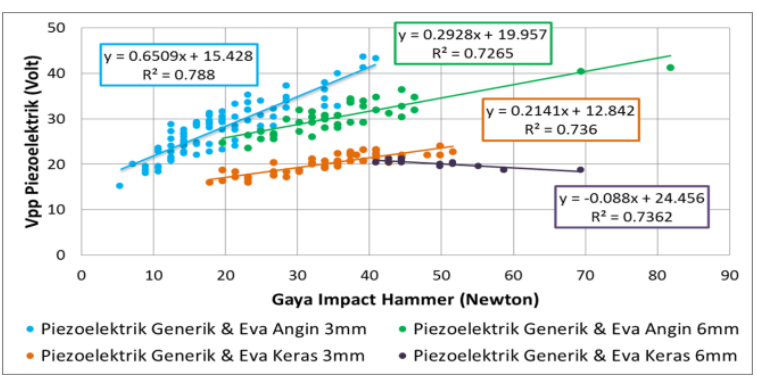

(b)

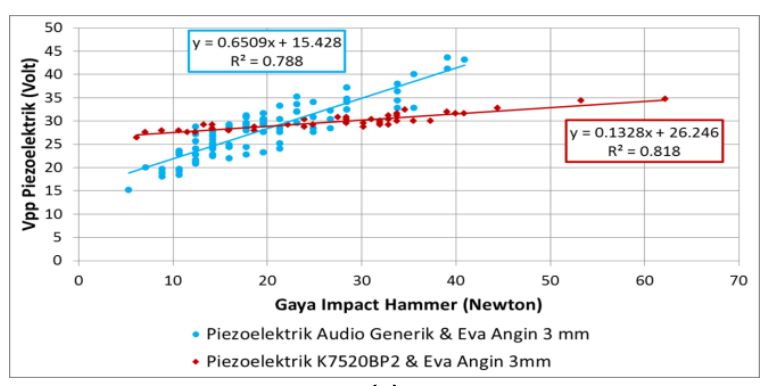

(c)

Gambar 8 Hasil Uji Impact Hammer (a) Tegangan Listrik Keluaran K7520BP2 (b) Tegangan Keluaran 
Piezoelektrik Audio Generik (c) Perbandingan Tegangan Keluaran antar Dua Tipe Piezoelektrik

Berdasarkan uji impact hammer, penambahan ketebalan insole dan variasi jenis material insole berpengaruh terhadap tegangan keluaran konfigurasi piezoelektrik. Variasi jenis material insole menentukan parameter massa insole (MEI) dan parameter konstanta pegas insole (KEI). Nilai konstanta pegas material yang lebih besar mengindikasikan bahwa material yang digunakan lebih kaku. Gambar 8 (a) dan (b) menunjukkan tegangan listrik yang dihasilkan konfigurasi dengan insole Eva-foam Angin bernilai lebih besar dibandingkan tegangan listrik yang dihasilkan pada konfigurasi dengan insole Eva-foam Keras. Konfigurasi nomor 1 (piezoelektrik K7520BP2 dengan insole Eva-foam Angin dan ketebalan 3 $\mathrm{mm}$ ) dan konfigurasi nomor 5 (piezoelektrik audio generik dengan insole berjenis Eva-foam Angin dan ketebalan $3 \mathrm{~mm}$ ) menghasilkan tegangan listrik terbesar. Ketika tegangan keluaran konfigurasi piezoelektrik nomor 1 dan 5 dibandingkan (Gambar 8 (c)), tegangan listrik yang dihasilkan konfigurasi nomor 1 lebih konsisten pada rentang pemberian gaya impact hammer.

Pada pelaksanaan uji konverter, terdapat lima konfigurasi yang menggabungkan piezoelektrik, yang menghasilkan tegangan keluaran terbaik berdasarkan hasil uji impact hammer, dengan konverter sebagaimana ditunjukkan Tabel 4.

Tabel 4 Variasi Sistem Sepatu Berpiezoelektrik

\begin{tabular}{|c|c|c|}
\hline $\begin{array}{c}\text { Sistem Sepatu } \\
\text { Berpiezoelektrik }\end{array}$ & $\begin{array}{c}\text { Nomor } \\
\text { Konfigurasi }\end{array}$ & $\begin{array}{c}\text { Jenis } \\
\text { Konverter }\end{array}$ \\
\cline { 1 - 1 } A & 1 & LTC 3588-1 \\
\cline { 1 - 1 } B & \multirow{2}{*}{5} & MB39C811 \\
\hline C & & LTC 3588-1 \\
\cline { 1 - 1 } D & MB39C811 \\
\hline E & 1* & MB39C811 \\
\hline
\end{tabular}

Sistem sepatu berpiezoelektrik E menggunakan konfigurasi piezoelektrik nomor 1 termodifikasi. Konfigurasi nomor 1 hanya memanfaatkan satu sisi piezoelektrik K7520BP2 sebagai masukan konverter MB39C811, sedangkan konfigurasi nomor 1 termodifikasi memanfaatkan kedua sisi piezoelektrik K7520BP2 sebagai masukan untuk konverter MB39C811.

Setiap sistem menghasilkan tegangan terukur berbeda pada kapasitor $0,1 \mathrm{mF}$ setelah 180 detik. Berdasarkan Gambar 9 (a), tegangan terukur pada kapasitor 0,1 mF terbesar didapatkan dari sistem sepatu berpiezoelektrik E sehingga sistem tersebut ditetapkan sebagai sistem sepatu berpiezoelektrik berperforma terbaik yang paling tepat untuk memanen energi dari aktivitas berjalan manusia.

Performa sistem sepatu berpiezoelektrik terpilih kemudian diuji dengan cara dihubungkan dengan kapasitor yang nilai kapasitansinya divariasikan. Pengujian ini menghasilkan tegangan terukur pada kapasitor $0,1 \mathrm{mF}$ sebesar 4,80Volt setelah 180 detik; tegangan terukur pada kapasitor $1 \mathrm{mF}$ mencapai 4,80Volt setelah 300 detik; dan tegangan terukur pada kapasitor $10 \mathrm{mF}$ mencapai 1,65Volt setelah 20 menit. Hal tersebut konsisten dengan prinsip kerja kapasitor, yaitu kapasitor berkapasitansi besar membutuhkan waktu lebih lama untuk mencapai tegangan terukur tertentu ketika dibandingkan dengan kapasitor berkapasitansi lebih kecil.

Karena itu, sistem sepatu berpiezoelektrik yang dipilih yaitu sistem dengan kapasitor berkapasitansi $10 \mathrm{mF}$ karena kapasitor berkapasitansi besar mampu menyimpan muatan lebih besar. Sistem sepatu berpiezoelektrik tersebut mampu menyimpan muatan listrik sebesar $16,5 \mathrm{mC}$ ketika mendapat masukan berfrekuensi $2 \mathrm{~Hz}$ selama 20 menit yang setara dengan 2400 langkah kaki manusia.

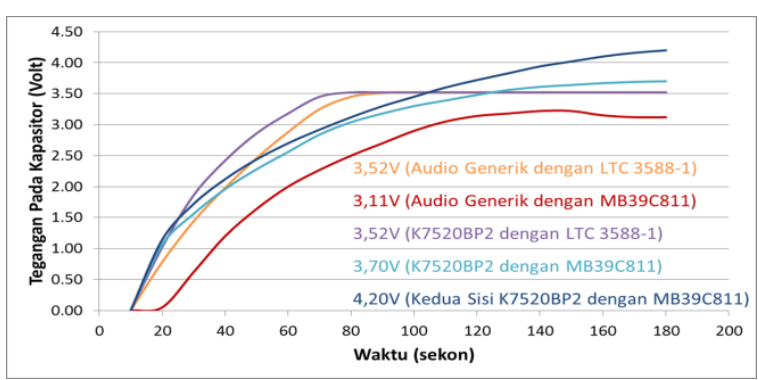

(a)

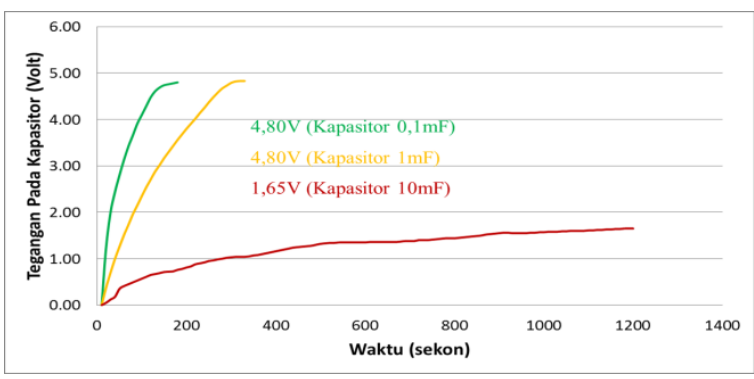

(b)

Gambar 9Hasil Uji Konverter (a) Tegangan Terukur Pada Kapasitor 0,1mF untuk Setiap Sistem (b) Tegangan Terukur Pada Kapasitor Ketika Mendapat Tegangan Masukan dari Konfigurasi Piezoelektrik K7520BP2 yang Memanfaatkan Kedua Sisinya Sebagai Masukan untuk Konverter MB39C811 dengan Insole Berjenis Eva-foam Angin dan Tebal $3 \mathrm{~mm}$. 


\section{Kesimpulan}

Sistem sepatu berpiezoelektrik yang terdiri dari integrasi konfigurasi piezoelektrik K7520BP2, yang memanfaatkan kedua sisinya sebagai masukan untuk konverter MB39C811 dengan insole berjenis Eva-foam Angin dan tebal $3 \mathrm{~mm}$ telah didesain pada studi ini. Sistem tersebut dipilih sebagai sistem berperforma terbaik serta yang paling tepat untuk memanen energi dari aktivitas berjalan manusia karena kemampuannya untuk menyimpan muatan listrik sebesar $16,5 \mathrm{mC}$ pada kapasitor $10 \mathrm{mF}$ ketika mendapat masukan berfrekuensi $2 \mathrm{~Hz}$ selama 20 menit yang setara dengan 2400 langkah kaki manusia.

\section{Ucapan Terima Kasih}

Penulis menyampaikan ucapan terima kasih kepada Program Kreativitas Mahasiswa 2015 Direktorat Jenderal Pendidikan Tinggi yang telah membantu pendanaan penelitian ini.

\section{Nomenklatur}

$\begin{array}{ll}\mathrm{B}_{\mathrm{EI}} & =\text { konstanta redaman insole } \\ \mathrm{B}_{\mathrm{EM}} & =\text { konstanta redaman midsole } \\ \mathrm{B}_{\mathrm{PZ}} & =\text { konstanta redaman piezoelektrik } \\ \mathrm{F} & =\text { Gaya } \\ \mathrm{K}_{\mathrm{EI}} & =\text { konstanta pegas insole } \\ \mathrm{K}_{\mathrm{EM}} & =\text { konstanta pegas midsole } \\ \mathrm{K}_{\mathrm{PZ}} & =\text { konstanta pegas piezoelektrik }\end{array}$

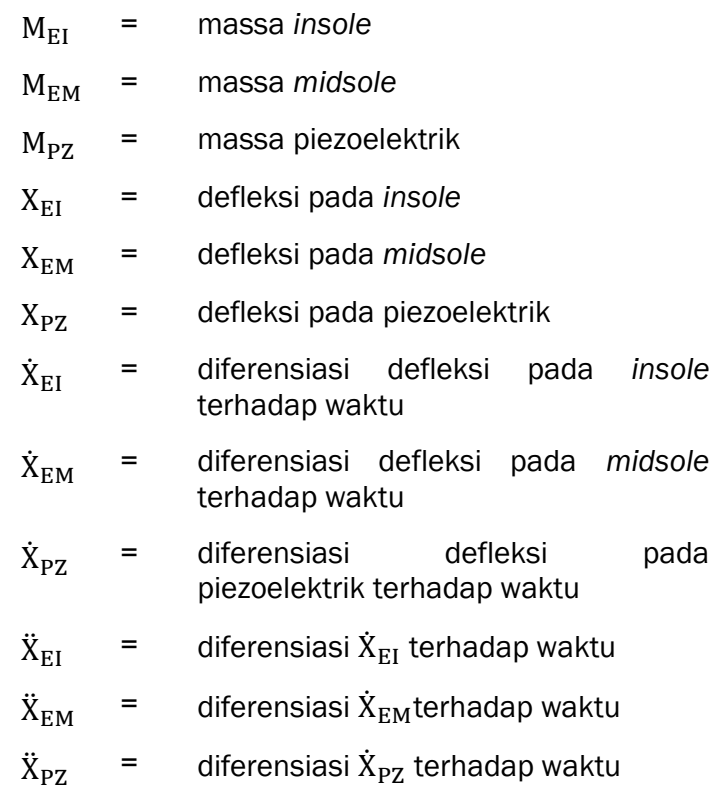

\section{Daftar Pustaka}

[1] T. Starner, "Human-powered wearable computing," IBM Syst. J., vol. 35, no. 3.4, pp. 618-629, 1996.

[2] J. Zhao and Z. You, "A shoe-embedded piezoelectric energy harvester for wearable sensors," Sensors, vol. 14, no. 7, pp. $12497-$ 12510,2014 . (references)

[3] D. Lieberman, M. Venkadesan, A. I. Daoud, and W. A. Werbel, "Biomechanics of Foot Strikes and Applications to Running Barefoot or in Minimal Footwear," Harv. Univ., 2010., in press.

[4] K. Ogata and Y. Yang, Modern Control Engineering 5th Edition,Prentice Hall, 2010. 